\title{
INVENTARISASI JENIS PAKAN LUTUNG JAWA (Trachypithecus auratus) PADA BLOK CILAME DAN BLOK CIMEUDEUM TAMAN WISATA ALAM GUNUNG TAMPOMAS KABUPATEN SUMEDANG
}

\author{
Inventory of Javan Langur's feed in Cilame and Cimeundeum Block Mt. \\ Tampomas Natural Tourism Park) \\ Raizal Fahmi; Vina Silvia Bintarawati \\ Universitas Winaya Mukti, J1. Raya Sumedang Km 29 Tanjungsari-Sumedang \\ 45362; fahutan@unwim.ac.id
}

\section{Diterima 4 Februari 2018 /Disetujui 22 Februari 2018}

\begin{abstract}
Javan Langur (Trachypithecus auratus) is one of folivora species by $50 \%$ leaves, $32 \%$ fruits, $13 \%$ flowers and 7\% insects. The most exist of J. langur in Mt. Tampomas Natural Tourism Park in Block of Cilame and Cimeundeum. Mt. Tampomas Natural Tourism Park is one of hiking trails that cause annoyed vegetation as J. Langur's feed. The objects of studies are to identify of Javan langur's feed and Importance Value Index of J. Langur's feed. The method is purposive sampling to know vegetation of feed. The result of species number were 62 species, include 18 species is a J. Langur's feed. The J. Langur's feed are kondang (Ficus variegata), nangsi (Villebrunea rubessen), kadoya (Dysoxylum gaudichaudianum), kiara (Fics altisima), kitambaga (Eugenia cuprea), gadog (Bischofia javanica), hamirung (Vernonia arborea), kibanen (Cryteronia paniculata), huru (Machilus rimota), afrika (Maesopsis eminii), putat (Bringtonia acutangular), sampang (Evodia latifolia), pisitan monyet (Glianthus populacus), kilalayu (Lepisanthes tetraphylla), kihuni (Antidesma bunius), hantap (Sterculia coccinea) dan saninten (Castanopsis argentea). Dominance of Javan Langur feed is kadoya (Dysoxylum gaudichaudianum), kitambaga (Eugenia cuprea), dan huru (Machilus rimota). This mean of habitat condition is available feed to J. langur existing.
\end{abstract}

Keywords: Javan Langur, feed, Tampomas natural tourism park 


\section{PENDAHULUAN}

Salah satu jenis primata endemik Indonesia yang penyebarannya terbatas hanya di daratan Pulau Jawa, Bali dan Lombok yaitu lutung. Lutung yang tersebar di Jawa Barat yaitu lutung jawa atau lutung budeng (Trachypithecus auratus). Habitat lutung jawa yaitu hidup di hutan bakau, hutan daratan rendah hingga hutan daratan tinggi baik primer maupun sekunder (Supriatna dan Wahyono, 2000). Lutung ini telah dilindungi sejak tahun 1999 berdasarkan keputusan menteri kehutanan dan perkebunan No:733/Kpts-II/1999. Pada tahun 2008 IUCN memasukkan Lutung jawa pada kategori Vulnerable (Rentan) terhadap gangguan habitat karena terus terdesak oleh kepentingan manusia. Spesies ini juga tercantum dalam CITES Appendix II.

Kawasan hutan Gunung Tampomas ditetapkan sebagai Taman Wisata Alam berdasarkan Surat Keputusan Menteri Pertanian Nomor : 423/Kpts/Um/7/1979, tanggal 5 Juli 1979 dengan luas areal \pm 1.250 Ha. Kawasan Taman Wisata Alam (TWA) Gunung Tampomas merupakan salah satu kawasan konservasi, karena memiliki keanekaragaman hayati baik flora maupun fauna dan berbagai tipe vegetasi dan merupakan sebuah habitat yang ideal bagi kelangsungan hidup satwa. Menurut hasil wawancara kepada pihak pengelola TWA Gunung Tampomas bahwa ditemukannya berbagai jenis primata di kawasan tersebut, salah satunya ditemukan keberadaan lutung jawa pada kawasan tersebut.

Blok Cilame dan Blok Cimeudeum merupakan salah satu blok yang terdapat di kawasan TWA Gunung Tampomas. Blok tersebut juga terdapat sumber air yang dijadikan satwa untuk memanfaatkan air untuk kelangsungan hidupnya. Menurut pengelola TWA Gunung Tampomas keberadaan lutung jawa yang paling sering dijumpai dibandingkan dengan blok lainnya yang ada di TWA Gunung Tampomas yaitu pada Blok Cilame dan Blok Cimeudeum.

Satwa ini bersifat folivora, dengan komposisi jenis pakan Lutung jawa yaitu $50 \%$ berupa daun, $32 \%$ buah, $13 \%$ bunga dan sisanya bagian dari tumbuhan atau serangga. Selain itu, Lutung jawa merupakan binatang diurnal. Sebagian besar aktifitasnya termasuk tidur dilakukan di atas pohon (arboreal) (Supriatna dan Wahyono, 2000).

Tipe penggunaan ruang secara arboreal dan persentase jenis pakan tersebut menunjukan bahwa kehidupan lutung jawa sangat tergantung pada keberadaan vegetasi hutan. Selain itu, jenis pohon pakan yang sangat berperan dalam mendukung kelangsungan hidup lutung jawa masih belum banyak diketahui pada kawasan tersebut. Kondisi demikian, perlu adanya penelitian mengenai jenis pakan bagi lutung jawa pada kawasan TWA Gunung Tampomas yaitu pada Blok 
Cilame dan Blok Cimeudeum, karena sampai saat ini masih minimnya penelitian mengenai hal tersebut. Pengetahuan jenis pakan lutung jawa yang terdapat di kawasan TWA Gunung Tampomas ini akan membantu mengurangi kepunahan populasi lutung jawa sebagai endemik di Indonesia yang persebarannya di Jawa Barat, dengan dilestarikannya jenis tumbuhan tersebut.

Pakan pada dasarnya merupakan faktor utama bagi kelangsungan hidup. TWA Gunung Tampomas di sisi lain merupakan tempat wisata bagi para pendaki sehingga banyak masyarakat memasuki kawasan hutan tersebut dan dikhawatirkan vegetasi hutan yang dijadikan sebagai sumber pakan lutung jawa pun akan terganggu karena ketidaktahuan masyarakat akan pakan tersebut. Terganggunya jenis pakan tersebut dikhawatirkan akan menyebabkan nilai INP dari pakan tersebut berkurang. Penelitian terhadap kebutuhan utama satwa berupa jenis pakan merupakan aspek yang berperan sangat penting sebagai upaya kelestarian satwa.

Hasil penelitian ini diharapkan dapat digunakan sebagai salah satu pertimbangan bagi pengelola TWA Gunung Tampomas untuk menentukan langkah-langkah yang tepat dalam pelestarian lutung jawa. Data penelitian ini juga diharapkan dapat memberikan informasi penting mengenai jenis pakan lutung jawa sehingga dapat dijadikan acuan dalam kegiatan pengelolaan habitat untuk pelestarian dan perlindungan vegetasi secara berkesinambungan.

\section{METODE PENELITIAN}

Penelitian dilakukan selama satu bulan pada bulan Juli 2017. Tempat penelitian di Kawasan Taman Wisata Alam (TWA) Gunung Tampomas Blok Cilame dan Blok Cimeudeum, yang terletak di Kecamatan Buahdua, Kabupaten Sumedang, Jawa Barat. Dengan luasan kawasan 191,37 Ha (Gambar 1). Alat yang digunakan dalam penelitian, antara lain : kamera, binokuler, GPS, tambang, alat tulis, phi-band, golok tebas, peta lokasi dan tallysheet jenis pakan serta tally sheet analisis vegetasi. Bahan yang digunakan adalah vegetasi pakan lutung jawa yang berada di TWA Gunung Tampomas. 


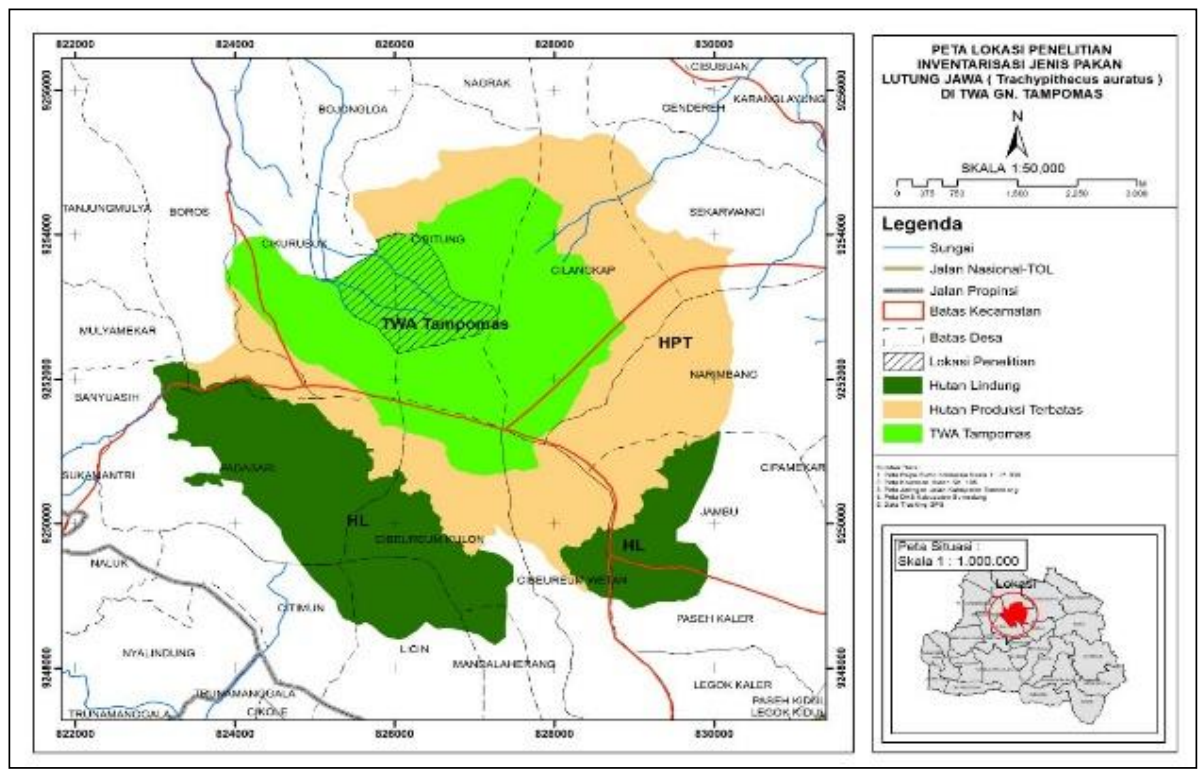

Gambar 1. Lokasi penelitian

Metode Pengumpulan Data dilakukan dengan survei pendahuluan dan pengamatan aktivitas makan. a) Survey Pendahuluan, dilakukan dengan wawancara kepada petugas Resort TWA Tampomas yang bertujuan untuk mendapatkan informasi mengenai keberadaan lutung jawa, dan jenis pakan yang dimakan oleh lutung jawa.

b). Pengamatan Aktivitas Makan Lutung Jawa, dilakukan dengan metode purpossive sampling, yaitu pengamatan dilakukan terhadap segala aktivitas makan lutung jawa, baik secara individu maupun kelompok. Data yang dikumpulkan meliputi, bagian dan jenis vegetasi yang dimakan oleh lutung jawa. Pengamatan dilakukan pukul 06.00-18.00 WIB sepanjang jalur pengamatan ditemukannya lutung jawa saat melakukan aktivitas makan. Penempatan plot dilakukan pada areal ditemukannya lutung jawa yang dianggap merupakan areal yang paling mewakili dan dilakukan selama 3 hari.

Analisis Data menggunakan analisis ruang dan analisis vegetasi. Analisis Ruang, dilakukan untuk mengolah data hasil inventarisasi jenis pakan lutung jawa, dimana dalam analisis ruang ini terfokuskan pada aktivitas lutung jawa saat makan dengan mengamati langsung jenis dan bagian dari pakan lutung jawa. Hasil dari pengamatan jenis pakan lutung jawa disajikan dalam bentuk tabel dan selanjutnya dianalisis secara deskriptif. 
Analisis Vegetasi, mengunakan metode Soerianegara dan Indrawan (2005) dengan metode garis berpetak. Luas areal yang analisis adalah 0,04 Ha dengan jarak antar plot sampling sejauh $100 \mathrm{~m}$ dan intensitas sampling sebesar 1\%. Jumlah plot sampling sebanyak 48 plot. Indeks Nilai Penting (INP) dihitung berdasarkan penjumlahan nilai Kerapatan Relatif (KR), Frekuensi Relatif (FR) dan Dominansi Relatif (DR). Hasil dari analisis vegetasi dikelompokkan menjadi beberapa kelompok status keamanan (Tabel 1). Tingkat keamanan tersebut bertujuan untuk melihat potensi pakan untuk jangka panjang, apakah diperlukan permudaan atau tidak.

Tabel 1. Status Keamanan Jenis Pakan Lutung Jawa

\begin{tabular}{ccc}
\hline No & $\begin{array}{c}\text { Kelompok } \\
\text { Status }\end{array}$ & Keterangan \\
\hline 1 & Sangat aman & $\begin{array}{r}\text { Vegetasi tersebut ditemukan pada setiap stratanya dan } \\
\text { mendominasi pada areal penelitian. } \\
\text { Vegetasi tersebut ditemukan pada setiap stratanya } \\
\text { tetapi jenis tersebut tidak mendominasi pada } \\
\text { areal penelitian. }\end{array}$ \\
3 & Aman & $\begin{array}{c}\text { Vegetasi tersebut tidak ditemukan pada salah satu } \\
\text { permudaannya atau lebih. } \\
\text { Vegetasi tersebut tidak ditemukan pada setiap } \\
\text { permudaan dan hanya ditemukan pada salah satu } \\
\text { strata saja. }\end{array}$ \\
\hline
\end{tabular}

\section{HASIL DAN PEMBAHASAN}

\section{Jenis Pakan Lutung Jawa}

Jenis pakan lutung jawa di TWA Gunung Tampomas terdiri dari berbagai jenis tumbuhan. Sesuai dengan pola hidup lutung jawa yang bersifat arboreal, sumber pakan lutung jawa yang ditemukan di lapangan adalah jenis vegetasi pada tingkat pohon.

Hasil pengamatan langsung di lapangan menunjukkan bahwa ada 12 jenis vegetasi yang menjadi pakan bagi lutung jawa (Tabel 2). Jenis vegetasi tersebut didapatkan saat pengamatan langsung di lapangan dengan menggunakan metode analisis ruang dan penempatan plot dibuat saat ditemukannya lutung jawa saat makan.

Data dilapangan juga menunjukan, bahwa lutung jawa lebih banyak mengkonsumsi daun dibandingkan dengan bagian dari pohon lainnya. Pernyataan tersebut juga dipertegas oleh Supriatna dan Wahyono (2000), bahwa Lutung lebih banyak mengkonsumsi daun dibandingkan dengan bagian tumbuhan lainnya. 
Dari 12 jenis pakan lutung jawa yang didapatkan pada lokasi penelitian, juga ada beberapa jenis yang didapatkan saat penelitian di tempat lain. Menurut Ribby dan Affan (2012) dalam penelitiannya di TBMK menyebutkan, bahwa lutung jawa mengkonsumsi jenis beunying (Ficus fitulosa) dan afrika (Maesopsis eminii). Sedangkan di TWA Gunung Tampomas hanya terlihat lutung jawa mengkonsumsi pohon afrika (Maesopsis eminii) dan untuk spesies beunying (Ficus fitulosa) hanya ditemukan pada strata pancang saja, sehingga lutung jawa lebih memilih mengkonsumsi strata pohon yang terdapat di lokasi penelitian, karena masih banyaknya potensi pohon untuk dikonsumsi lutung jawa.

Tabel 2. Jenis vegetasi pakan lutung jawa

\begin{tabular}{|c|c|c|c|}
\hline Nama Lokal & Nama Latin & Famili & $\begin{array}{c}\text { Bagian yang } \\
\text { dimakan }\end{array}$ \\
\hline Kondang & Ficus variegata & Moraceae & Daun \\
\hline Nangsi & Villebrunea rubessen & Urticaceae & Daun, Buah \\
\hline Kadoya & $\begin{array}{l}\text { Dysoxylum } \\
\text { gaudichaudianum }\end{array}$ & Meliaceae & Daun \\
\hline Kiara & Ficus altisima & Moraceae & Daun, Buah \\
\hline Kitambaga & Eugenia cuprea & Myrtaceae & Daun \\
\hline Gadog & Bischofia javanica & Rubiaceae & Daun \\
\hline Hamirung & Vernonia arborea & Asteraceae & Daun \\
\hline Kibanen & Cryteronia paniculata & Crypteroniaceae & Daun \\
\hline Huru & Machilus rimota & Lauraceae & Buah \\
\hline Afrika & Maesopsis eminii & Rhamnaceae & Daun, Buah \\
\hline Putat & Baringtonia acutangular & Lecythidaceae & Daun \\
\hline Sampang & Evodia latifolia & Rutaceae & Daun \\
\hline
\end{tabular}

Sumber : Data primer lapangan (2017)

Menurut penelitian Riyadi (2010) di Cagar Alam Talaga Warna Kabupaten Bogor, menyebutkan untuk jenis pakan lutung jawa terdapat 36 jenis, data tersebut didapat berdasarkan data dari BKSDA Jawa Barat dan hasil pengamatan langsung di lapangannya. Jenis vegetasi yang sama dikonsumsi oleh lutung jawa diantaranya kondang (Ficus variegata), kiara (Ficus altisima), huru (Machilus rimota) dan putat (Baringtonia acutangular). Selain itu, ada juga vegetasi yang sama tetapi di Blok Cilame dan Blok Cimeudeum tidak ditemukannya lutung jawa sedang mengkonsumsi jenis vegetasi tersebut, diantaranya pisitan monyet (Glianthus populacus), kilalayu (Lepisanthes tetraphylla), kihuni (Antidesma bunius), hantap (Sterculia coccinea), dan saninten (Castanopsis argentea). Sehingga jenis pakan lutung jawa yang ada di TWA Gunung Tampomas terdapat 18 spesies. Hal tersebut, menandakan bahwa potensi 
pakan lutung jawa pada Blok Cilame dan Blok Cimeudeum masih banyak tersedia untuk dikonsumsi lutung jawa.

Profil vegetasi yang digunakan sebagai pohon pakan di Blok Cilame dan Blok Cimeudeum ini sebagian merupakan pohon-pohon yang berjarak jauh dari jalur pengamatan atau perlintasan manusia, hal ini dilakukan untuk menghindari kucing hutan yang merupakan predator lutung jawa dan untuk menghindari interaksi dengan manusia. Selain itu, lebar tajuk pohon pakan umumnya memiliki kedua sisi yang lebar, sehingga antara tajuk pohon satu dengan lainnya saling berhubungan, hal tersebut akan memudahkan lutung jawa dalam melakukan pergerakan dari satu pohon ke pohon lainnya karena pada dasarnya lutung jawa merupakan hewan arboreal.

\section{Komposisi Vegetasi}

Farida dan Harun (2000) mengemukakan bahwa untuk mempertahankan keberadaan primata di habitat alaminya, perlu dilakukan identifikasi terhadap keanekaragaman jenis tumbuhan yang ada karena tumbuhan-tumbuhan ini sebagian merupakan sumber pakan bagi primata yang hidup di habitat tersebut.

Keberadaan lutung jawa di TWA Gunung Tampomas juga didukung dengan vegetasi yang terdapat di dalamnya, yang secara umum pohon yang dimanfaatkan sebagai pohon pakan dapat diidentifikasi di setiap tingkat permudaan. Berdasarkan hasil analisis vegetasi yang dilakukan dilapangan ditemukannya 62 jenis vegetasi mulai dari semai, pancang, tiang dan pohon. Terdapat 32 jenis vegetasi pada tingkat semai, 32 jenis pada tingkat pancang, 31 jenis pada tingkat tiang dan 29 jenis pada tingkat pohon. Dari data tersebut didapat lima diantaranya yang paling mendominasi pada setiap stratanya (Tabel $3)$.

Jenis yang dominan diperkirakan merupakan jenis yang lebih adaptif terhadap lingkungan atau mampu menyesuaikan diri pada lingkungan tempat hidupnya. Suatu jenis dikatakan dominan dalam komunitas apabila jenis tersebut berhasil memanfaatkan sebagian besar sumber daya yang ada untuk pertumbuhan hidupnya dibandingkan dengan jenis lain (Alikodra dan Srimulyaningsih, 2015). Tabel 3 menunjukkan kerapatan individu suatu jenis. Kerapatan pohon bagi satwa arboreal sangat diperlukan untuk pergerakan dan perpindahan baik untuk mencari makan, istirahat dan prilaku sosial. Spesies yang mempunyai kerapatan relatif tertinggi diantara lima jenis vegetasi yang mendominasi untuk strata semai yaitu angrit (Kopsia sp) sebesar 17.14\%, untuk strata pancang yaitu huru (Machilus rimota) sebesar $14.49 \%$, untuk strata tiang yaitu huru (Machilus rimota) sebesar $13.91 \%$, dan untuk strata pohon yaitu huru (Machilus rimota) sebesar 13.13\%. 
Perbedaan nilai kerapatan masing-masing jenis disebabkan karena adanya perbedaan kemampuan regenerasi, penyebaran dan adaptasi yang lebih baik terhadap lingkungan.

Frekuensi menggambarkan persebaran suatu spesies pada suatu areal. Spesies yang mempunyai frekuensi relatif tertinggi diantara lima spesies yang mendominasi untuk strata semai yaitu angrit (Kopsia sp) sebesar 16.06\%, untuk strata pancang yaitu angrit (Kopsia sp) sebesar 14.59\%, untuk strata tiang yaitu angrit (Kopsia sp) sebesar 15.12\%, dan untuk strata pohon yaitu huru (Machilus rimota) sebesar $10.87 \%$. Nilai frekuensi tertinggi menunjukan bahwa jenis vegetasi tersebut memiliki persebaran yang lebih merata dan lebih mudah dijumpai di lokasi pengamatan.

Tabel 3. Dominanansi vegetasi setiap strata

\begin{tabular}{clcccc}
\hline Strata & \multicolumn{1}{c}{ Jenis } & $\begin{array}{c}\text { KR } \\
(\boldsymbol{\%})\end{array}$ & $\begin{array}{c}\text { FR } \\
(\boldsymbol{\%})\end{array}$ & $\begin{array}{c}\text { DR } \\
(\boldsymbol{\%})\end{array}$ & $\begin{array}{c}\text { INP } \\
(\boldsymbol{\%})\end{array}$ \\
\hline \multirow{5}{*}{ Semai } & 17.14 & 16.06 & - & 33.21 \\
& Angrit & & & & \\
& Gadog & 10.18 & 8.81 & - & 18.99 \\
& Huru & 6.07 & 8.29 & - & 14.36 \\
& Kadoya & 11.96 & 14.51 & - & 26.47 \\
& Kitambaga & 11.25 & 9.33 & - & 20.58 \\
& Angrit & 13.86 & 14.59 & - & 28.45 \\
& Huru & 14.49 & 13.46 & - & 27.95 \\
Pancang & Kadoya & 11.21 & 10.10 & - & 21.31 \\
& Kitambaga & 4.83 & 8.42 & - & 13.24 \\
& Pingku & 9.97 & 11.22 & - & 21.19 \\
& Angrit & 9.11 & 15.12 & 9.03 & 33.26 \\
& Dahu & 8.11 & 9.27 & 7.26 & 24.64 \\
& Huru & 13.91 & 12.68 & 13.14 & 39.73 \\
& Kadoya & 10.43 & 8.29 & 10.73 & 29.45 \\
& Kitambaga & 10.76 & 11.71 & 11.23 & 33.70 \\
& Huru & 13.13 & 10.87 & 10.99 & 34.98 \\
& Kadoya & 11.04 & 9.78 & 13.80 & 34.62 \\
& Kiara & 10.21 & 8.15 & 11.40 & 29.76 \\
& Kitambaga & 10.00 & 8.15 & 7.80 & 25.95 \\
& Sempur & 4.38 & 8.15 & 4.86 & 17.39 \\
\hline \multirow{6}{*}{ Pohon } & & Sumber : Data yang diolah, 2017 \\
& & & & &
\end{tabular}

Nilai dominansi masing-masing spesies juga bervariasi. Nilai dominansi masing-masing spesies dihitung berdasarkan besarnya nilai diameter batang setinggi dada. Spesies yang mempunyai nilai dominansi relatif tertinggi diantara 
lima spesies yang mendominasi untuk strata tiang yaitu huru (Machilus rimota) sebesar $13.14 \%$ dan untuk strata pohon yaitu kadoya (Dysoxylum gaudicaudianaum) sebesar $13.80 \%$. Hal ini menunjukan bahwa spesies tersebut memiliki luas bidang dasar (penguasaan lahan oleh batang pohon) yang lebih tinggi dibandingkan jenis-jenis lainnya.

Indeks Nilai Penting suatu jenis menggambarkan peranan suatu spesies tersebut dalam suatu komunitas. Terdapat lima vegetasi yang dominan dari masing-masing vegetasi lain. Untuk strata semai yang medominasi pada lokasi penelitian yaitu jenis angrit (Kopsia sp) sebesar 33.21\%. Untuk strata pancang didominasi oleh jenis angrit (Kopsia $s p$ ) sebesar 28.45\%. Untuk strata tiang didominasi oleh jenis huru (Macaranga rhizinoides) sebesar 39.73\%. Dan untuk strata pohon juga sama didominasi oleh jenis huru (Macaranga rhizinoides) sebesar 34.98\%. Indeks Nilai Penting (INP) pada jenis-jenis yang memiliki nilai tertinggi dapat disebabkan oleh beberapa faktor diantaranya tempat tumbuh atau faktor lingkungan yang mendukung keberadaan jenis ini, kemampuan beradaptasi dengan lingkungan serta dapat mengembangkan diri secara cepat pada habitatnya.

\section{Ketersediaan Pakan}

Ketersediaan pakan lutung jawa dianalisis mulai dari permudaan setiap vegetasinya dan mewakili setiap strata (Gambar 2). Dilihat dari gambar tersebut, untuk jenis kondang (Ficus variegata) ditemukan pada setiap stratanya dengan nilai INP pada semai sebesar $4.93 \%$, pancang sebesar $3.08 \%$, tiang sebesar $5.01 \%$ dan untuk pohon sebesar 5.14\%. Meskipun Kondang (Ficus variegata) tidak mendominasi pada areal tersebut tetapi jenis pakan ini dapat dikatakan aman untuk dikonsumsi jangka panjang karena dari setiap permudaannya terdapat jenis tersebut untuk regenerasi kedepannya.

Jenis nangsi (Villebrunea rubescens) ditemukan pada setiap stratanya, dengan nilai INP pada semai sebesar $5.98 \%$, pancang sebesar $6.64 \%$, tiang sebesar $7.63 \%$ dan pohon sebesar $5.45 \%$. Meskipun jenis ini tidak mendominasi pada areal tersebut tetapi jenis pakan ini dapat dikatakan aman untuk dikonsumsi jangka panjang karena masih ditemukannya jenis permudaan untuk regenerasi kedepannya. 


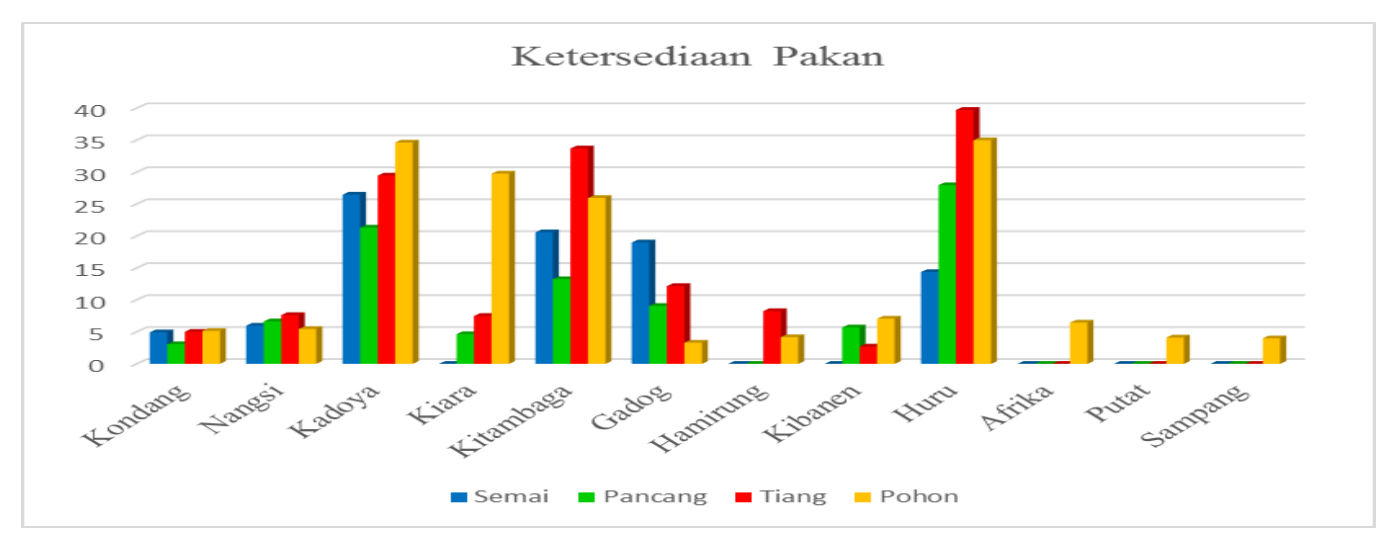

Gambar 2. Ketersediaan pakan lutung jawa

Jenis kadoya (Dysoxylum gaudichaudianum) ditemukan pada setiap stratanya, dengan nilai INP pada semai sebesar $26.47 \%$, pancang sebesar $21.31 \%$, tiang sebesar $29.45 \%$ dan pohon sebesar $34.62 \%$. Jenis pakan ini mendominasi pada areal tersebut dan dapat dikatakan sangat aman untuk dikonsumsi jangka panjang karena dilihat dari setiap permudaannya yang ada jenis ini memiliki nilai INP cukup tinggi untuk regenerasi kedepannya.

Jenis kiara (Ficus altisima) tidak ditemukan pada strata semai, untuk nilai INP pada strata pancang sebesar $4.64 \%$, tiang sebesar $7.49 \%$, dan pohon sebesar $29.76 \%$. Jenis pakan ini meskipun nilai INP dari pohon cukup tinggi tetapi untuk strata semai tidak ditemukan, maka pakan ini dapat dikatakan tidak aman untuk dikonsumsi jangka panjang karena jenis pakan ini tidak mampu untuk regenerasi kedepannya, meskipun dapat beregenerasi tetapi membutuhkan waktu yang lama untuk pertumbuhannya.

Jenis kitambaga (Eugenia cuprea) ditemukan pada setiap stratanya, dengan nilai INP pada semai sebesar $20.58 \%$, pancang sebesar $13.24 \%$, tiang sebesar $33.70 \%$ dan pohon sebesar $25.95 \%$. Jenis pakan ini mendominasi pada areal tersebut dan dapat dikatakan sangat aman untuk dikonsumsi jangka panjang karena dilihat dari setiap permudaannya jenis ini memiliki nilai INP cukup tinggi untuk regenerasi kedepannya.

Jenis gadog (Bischofia javanica) ditemukan pada setiap stratanya, dengan nilai INP pada semai sebesar $18.99 \%$, pancang sebesar $9.07 \%$, tiang sebesar $12.17 \%$ dan pohon sebesar $3.30 \%$. Meskipun jenis ini tidak mendominasi pada areal tersebut tetapi jenis pakan ini dapat dikatakan aman untuk dikonsumsi jangka panjang karena masih ditemukannya jenis permudaan untuk regenerasi kedepannya. 
Jenis hamirung (Vernonia arborea) tidak ditemukan pada strata semai dan pancang, dengan nilai INP pada tiang sebesar $8.25 \%$ dan pohon sebesar $4.18 \%$. Jenis pakan ini dikatakan tidak aman untuk dikonsumsi jangka panjang karena tidak ditemukannya pada strata semai dan pancang sehingga jenis pakan ini tidak mampu untuk regenerasi kedepannya, meskipun dapat beregenerasi tetapi membutuhkan waktu yang lama untuk pertumbuhannya.

Jenis kibanen (Criyteronia paniculata) tidak ditemukan pada strata semai, dengan nilai INP pada pancang sebesar $5.70 \%$, tiang sebesar $2.70 \%$ dan pohon sebesar $7.07 \%$. Jenis pakan ini dikatakan tidak aman untuk dikonsumsi jangka panjang karena tidak ditemukannya pada strata semai sehingga jenis pakan ini tidak mampu untuk regenerasi kedepannya, meskipun dapat beregenerasi tetapi membutuhkan waktu yang lama untuk pertumbuhannya.

Jenis huru (Machilus rimota) ditemukan pada setiap stratanya, dengan nilai INP pada semai sebesar $14.36 \%$, pancang sebesar $27.95 \%$, tiang sebesar $39.73 \%$ dan pohon sebesar $34.98 \%$. Jenis pakan ini mendominasi pada areal tersebut dan dapat dikatakan sangat aman untuk dikonsumsi jangka panjang karena dilihat dari setiap permudaan yang ada jenis ini memiliki nilai INP cukup tinggi untuk regenerasi kedepannya.

Jenis afrika (Maesopsis eminii) tidak ditemukan pada strata semai, pancang dan tiang, dengan nilai INP pada pohon sebesar $6.45 \%$. Jenis pakan ini dikatakan sangat tidak aman untuk dikonsumsi jangka panjang karena tidak ditemukannya pada strata semai, pancang dan tiang, sehingga jenis pakan ini tidak mampu untuk regenerasi kedepannya, meskipun dapat beregenerasi tetapi membutuhkan waktu yang lama untuk pertumbuhannya.

Jenis putat (Vlanchonia valida) tidak ditemukan pada strata semai, pancang dan tiang dengan nilai INP pada pohon sebesar 4.11\%. Jenis pakan ini dikatakan sangat tidak aman untuk dikonsumsi jangka panjang karena tidak ditemukannya pada strata semai, pancang dan tiang, sehingga jenis pakan ini tidak mampu untuk regenerasi kedepannya, meskipun dapat beregenerasi tetapi membutuhkan waktu yang lama untuk pertumbuhannya.

Jenis sampang tidak ditemukan pada strata semai, pancang dan tiang dengan nilai INP pada pohon sebesar 3.99\%. Jenis pakan ini dikatakan sangat tidak aman untuk dikonsumsi jangka panjang karena tidak ditemukannya pada strata semai, pancang dan tiang, sehingga jenis pakan ini tidak mampu untuk regenerasi kedepannya, meskipun dapat beregenerasi tetapi membutuhkan waktu yang lama untuk pertumbuhannya.

Dari 12 jenis pohon pakan yang terdapat di Blok Cilame dan Blok Cimeudeum TWA Gunung Tampomas memiliki tingkat keamanan masing- 
masing untuk dikonsumsi jangka panjang. Dilihat dari uraian tersebut ada beberapa jenis yang tidak terdapat pada setiap permudaannya. Hal ini dapat disebabkan karena pertumbuhan tingkat semai terganggu. Kurangnya pertumbuhan tingkat semai diperkirakan karena beberapa hal, diantaranya :

1. Terhambatnya proses persemaian secara alami untuk sampai di lantai hutan karena bisa jadi tebalnya tumbuhan bawah disekitarnya.

2. Tidak menentunya musim penghujan dan kemarau yang menyebabkan beberapa jenis sulit untuk berbunga dan berbuah sehingga tidak dapat melakukan persemaian secara alami.

3. Kesesuaian tempat tumbuh juga berpengaruh terhadap pertumbuhan suatu spesies.

Walaupun demikian, masih banyaknya spesies yang pertumbuhannya ditemukan pada semua stratanya khususnya untuk jenis pakan lutung jawa. Hal tersebut menunjukan bahwa jenis pakan di Blok Cilame dan Blok Cimeudeum ini masih cukup baik untuk memenuhi kebutuhan makan lutung jawa.

\section{KESIMPULAN}

Pakan lutung jawa yang berada blok Cilame dan blok Cimeundeum dapat disimpulkan bahwa :

1. Terdapat 62 jenis vegetasi di Blok Cilame dan Blok Cimeudeum dan 12 diantaranya merupakan jenis pakan lutung jawa. Jenis pakan tersebut antara lain : kondang (Ficus variegata), nangsi (Villebrunea rubessen), kadoya (Dysoxylum gaudichaudianum), kiara (Ficus altisima), kitambaga (Eugenia cuprea), gadog (Bischofia javanica), hamirung (Vernonia arborea), kibanen (Cryteronia paniculata), huru (Macaranga rhizinoides), afrika (Maesopsis eminii), putat (Baringtonia acutangular), dan sampang (Euodia latifolia).

2. Vegetasi yang memiliki kategori tingkat keamanan "sangat aman" untuk regenerasi ke depannya yaitu kadoya (Dysoxylum gaudichaudianum), kitambaga (Eugenia cuprea), dan huru (Machilus rimota).

\section{DAFTAR PUSTAKA}

Alikodra, H.S dan R. Srimulyaningsih. 2015. Bekantan: Perjuangan Melawan Kepunahan. IPB Press. Bogor.

Alikodra, H.S, Efransjah, M. Bismark. 2015. Bekantan: Perjuangan Melawan Kepunahan. IPB Press. Bogor.

Farida, W.R dan Harun. 2000. Keragaman Jenis Tumbuhan sebagai Sumber Pakan bagi Owa Jawa (Hylobates moloch), Surili (Presbytis comata), dan 
Lutung (Trachypithecus auratus) di Taman Nasional Gunung Halimun. Jurnal Primatologi Indonesia Vol 3 (2): 55-61.

IUCN. 2014. IUCN Red List of Threatened Species. International Union for Conservation of Nature (IUCN), Species Survival Commission (SSC), Gland, Switzerland and Cambridge, UK. www.iucnredlist.org.

Riyadi, D.S. 2010. Analisis Habitat Lutung (Trachypithecus auratus) di Cagar Alam Talaga Warna Kabupaten Bogor Jawa Barat. Skripsi. Fakultas Kehutanan UNWIM. Sumedang.

Soerianegara, I. dan A. Indrawan. 2005. Ekosistem Hutan Indonesia. Laboratorium Ekologi Hutan. Fakultas Kehutanan. Institut Pertanian Bogor.

Supriatna, J. dan E.H. Wahyono. 2000. Panduan Lapangan Primata Indonesia. Yayasan Obor Indonesia. Jakarta. 